\title{
Refugee Women Resettling in the United States at Mid-Life after Ethnic Cleansing
}

\author{
Stevan M. Weine and Dolores Vojvoda
}

\begin{abstract}
This is a case study of two women resettling in the United States after surviving ethnic cleansing in Bosnia and a discussion of refugee women at mid-life. We learned about their lives through their participation in testimony and biographical interviewing. Daniel Levinson's study of women's lives provides a frame for thinking about the refugee woman's life after ethnic cleansing. The mid-life refugee woman's experience in the private and public spheres is changed by their traumas, but also by the transition from early to middle adulthood. Her recovery will be further shaped by the contours of her continued adult development as will the lives of her children.
\end{abstract}

\section{Précis}

Ceci est une étude de cas portant sur deux femmes s'installant pour vivre aux États-Unis après avoir survécu à l'expérience de la purification ethnique en Bosnie. Il s'agit aussi d'une discussion de la question de la femme quadragénaire réfugiée. Nous avons eu accès aux détails de la vie de ces deux femmes grâce à leur participation à des témoignages et à des entrevues à visée biographique. L'étude de Daniel Levinson sur la vie de la femme produit le cadre de départ permettant de poser le problème de la vie de la femme réfugiée après le drame de la purification ethnique. L'expérience de la femme quadragénaire dans les sphères publiques et privées est tranformée par le traumatisme qu'elle a

Stevan M. Weine, M.D., is working with The Project on Genocide, Psychiatry, and Witnessing, University of Illinois at Chicago Psychiatric Institute, Chicago IL, USA.

Dolores Vojvoda, M.D., is affiliated with the Department of Psychiatry at the Yale School of Medicine and the West Haven Veterans Administration, New Haven CT, USA. vécu, mais tout autant par la transition qui la voit passer de jeune adulte à adulte mûre. Son rétablissement sera désormais façonné par le profil de son développement continu dans la vie adulte. Il en est autant de la vie de ses enfants.

\section{Trauma and Refugee Women's Lives}

The knowledge gained from mental health work with refugee women in a variety of sociohistorical contexts has appropriately drawn attention to the suffering of refugee women and served as the fundament for the current work with refugee women from Bosnia-Herzegovina. Yet the demands of this new work have made the gaps in that knowledge ever more clear. The mental health literature on refugee women has only begun to draw attention to the interactions between the psychiatric sequelea of traumatization (i.e,, Post Traumatic Stress Disorder) and the familial, social, and cultural contexts of women's lives. In addition, the conditions of Bosnian refugee women has presented yet new challenges.

The most widely publicized issue in this respect has concerned the mass rape of Bosnian women, about which there have been many reports in the mass media. Rape survivors' testimonies and secondhand reports tend to focus on what has been shattered, lost or destroyed in their lives as a result of the rapes. The tendency to focus exclusively on what is broken in survivors also appears in the psychiatric literature, with its preoccupation with Post Traumatic Stress Disorder. Our ongoing experience working with many Bosnian women refugees resettling in the United States suggests that these foci, sexual traumas and severe psychiatric symptoms, however legitimate, do not provide an accurate representa- tion of the majority of Bosnian refugee women's lives.

We wanted to find another language for talking about these women's experiences that did not focus exclusively on refugee traumas, nor overly objectify their experiences by using medical terminology, but also did not ignore the harsh transformations in their lives. We wanted to learn in more concrete details about the changes in their lives, but we also wanted to be able to reflect on the processes of struggle, recovery and growth that we observed.

Daniel Levinson's The Seasons of a Woman's Life studies the lives of 45 women from the vantage point of adult life structure developmental theory. Although his study did not include Bosnian refugees nor traumatized women, his concepts provide a way of guiding an inquiry into the refugee women's lives. Levinson's central idea is that of life structure, which encompasses "the person's relationship with various others in the external world" (ibid., 23), including the dimensions of:

(1) what the Person and the Other do with each other; (2) the subjective meanings involved; (3) what the Person gives and receives-materially, emotionally, socially; (4) the social context of the relationship; (5) the place of the relationship in the person's life structure and how it connects to other relationships; (6) its evolution over time within the life structure. (ibid., 23)

A woman's life cycle is seen as a sequence of specific eras, each with its own developmental opportunities and challenges. Levinson described the mid-life transition, from ages 40 to 45 , as the important life structure changing period that comes at the end of youth, and involves renegotiating the places of work and family in the life. 
Another major theme in women's lives that Levinson discussed pertains to gender splitting, the "splitting asunder" (ibid., 38) in women's lives in four ways: "1) the domains of the domestic sphere versus the public sphere; 2) the female homemaker and the male provisioner; 3) women's work and men's work; 4) feminine and masculine in the individual psyche" (ibid., 38-39).

Writing from another vantage point about refugee women, the psychologist Inger Agger (1992, 2) asked if their exile could be "an existential situation for women who wish to abandon their silent and invisible lives in an androcentric culture." We were interested in approaching this question by looking at the impact of refugee trauma on women's lives guided by Levinson's approach. This paper looks at two women and discusses the patterns of women's experiences in the public and private spheres in refugees lives at mid-life transition.

\section{Testimony, Intensive Biographical Interviewing, and Refugee Women's Lives}

In testimony, the survivor tells the story of what happened when traumas shattered their life, and the psychiatrist or psychotherapist is the witness who records it. Together they make a document of the survivor's trauma story, and then look for appropriate ways to make the survivor's story knowable to others. In testimony, survivors do not speak only of their trauma story, but also of their participation in the way of life that was, and of what kind of future they foresee, for themselves and the collectives to which they belong.

In The Blue Room, Inger Agger used the testimony approach to explore the life experiences of refugee women. Agger's exploration focused on sexual traumas and other gender specific abuses. Testimony was about "one sex's painful struggle to extend its space-to move the boundaries of the permissible and fight the power of shame" (ibid., 1). Agger describes the narrative which she wrote as a:

... narrative about boundaries ...

About bodily, psychological, cul- tural, social and political boundaries ... about barriers that are overcomeabout crossing borders and having your boundaries violated-and about being in the ambiguous borderland where you have to be careful of your own, other people's and the system's boundaries. (ibid., 1 )

Our work with Bosnian refugee women, the majority of whom did not suffer sexual traumas, compelled us to look at the issues of "boundaries" in women's lives, though from a different perspective. In testimony, women would tell us about their life struggles to reconcile differing positions with respect to family and work, and to make choices about their role and identity. Testimony of this nature overlapped with Levinson's descriptions of Intensive Biographical Interviewing which was the method used in his research on women's lives.

Like testimony, Intensive Biographical Interviewing involves the joint effort to tell and document a story. However, Intensive Biographical Interviewing focuses not on a traumatic experience, but on the persons' life story. It aims to give a rich and full account of the life, but also to reflect conceptually about the life's "underlying complexity, order and chaos" (ibid., 9). Whereas testimony is organized around trauma and healing, Intensive Biographical Interviewing is organized by the life structure and its development. Testimony speaks of boundaries, their shattering, and redefinition; whereas Intensive Biographical Interviewing speaks about building and changing life structure, and its satisfactoriness, both externally "how well it works" (ibid., 28) and internally "suitability for the self" (ibid., 29).

Our dialogues with refugee women from Bosnia combined testimony and Intensive Biographical Interviewing because both seemed necessary. Testimony was a way of addressing the traumas of the survivor, and Intensive Biographical Interviewing was a way of addressing the adult developmental struggles of the refugee women. The following section presents condensed accounts and samplings of the voices of two Bosnian refugee women at midlife.

\section{Two Bosnian Refugee Women at Mid-Life}

\section{Mrs. Hasan}

Mrs. Hasan is a tall, strong women with a pleasant face, in her early forties. Her hands and face show traces of years of hard work. She grew up in a small village in Bosnia, where her parents were farmers. She worked before and after school on their land as long as she can remember. At age 16, she met her husband, several years her senior, dropped out of school, got married, and moved with him to a neighbouring village. After a few years, they bought their own piece of land, and had two children, a boy and a girl, who are now adolescents. Her husband worked as a carpenter, and Mrs. Hasan was in charge of the house, farm and small grocery shop that they bought several years before the war. Even though she was contributing to the household just as much as her husband was Mrs. Hasan's husband was the "boss" in the family. Although they always talked before making major decisions, his word was the final one.

The breakup of the former Yugoslavia and the ensuing violence in the spring of 1992 had found the family unprepared.

\begin{abstract}
One day my husband got on a bus to Croatia, and several miles away from our village was taken off the bus by the Serbs and taken to the concentration camp ... My children and I were lined up to die in front of a firing squad, and a Serbian neighbour saved us at the last moment. We had to march for miles, almost got separated several times. The children were forced to walk past and to sleep in the fields next to the dead bodies of our neighbours. I did not know for months if my husband was alive.
\end{abstract}

The family was reunited in Zagreb, Croatia. There, Mrs. Hasan cut off her long hair that she had groomed for many years. "I finally realized then 
that the old way of life, the only way we knew, was over."

We met the family just a few weeks after they arrived in the United States from Croatia. In that first meeting Mrs. Hasan was silent; Mr. Hasan was the spokesman for the family. He told us they were doing fine. He just wanted to put his family back on their feet. Later on, when her husband was not in the room, Mrs. Hasan said that not everything was "fine." "I have been waking up every night with a nightmare and I have been crying daily since we left home. People are telling me-you are lucky to be in America, but I want to be home, where I belong."

Mrs. Hasan was the one her family allowed to be in distress. She was allowed to cry and leave the room when TV news showed the war in Bosnia. She recognized that this was because she, as a woman, could be "weak" in her family's eyes. A few months after their arrival, she reported:

My husband got a job and the children started going to school. I have been staying at home, alone. I am feeling isolated, and do not like this way of life. I was used to working hard. Now I have too much time on my hands. And too many bad memories.

Mr. Hasan was often away from the home, working several jobs. At home he kept silent about what had happened while he was in a concentration camp, and she never told him about the horrors she went through with their children. "Athome, we never talk about what had happened in Bosnia." But news from Bosnia kept reaching them:

I received a letter from my brother with bad news about our family's daily perils in Bosnia. I was so upset that I could not stop crying. I also got a headache so strong that the sponsors had to take me to the Emergency Room to get an analgesic. I tried to tell my husband how badly I was feeling but he just told me that our new life was here, in the U.S., not back in Bosnia.

Mr. Hasan took on twojobs and was at home even less than before. Mrs.
Hasan started English classes, and their sponsors tried to find her a job. She interviewed for a job as a saleswomen, but the manager was looking for somebody with more a fashionable hairstyle. Mrs. Hasan did not feel ready to change her ways, so she did not get the job.

Mrs. Hasan noticed that her daughter was having trouble sleeping and was upset when talking about Bosnia. Her worries were confirmed when the school psychologist suggested counselling for her. Mr. Hasan objected; in his opinion; the girl just needed to "toughen up." Quietly and persistently, Mrs. Hasan managed to arrange for her child's treatment. After several months of psychotherapy, she was doing much better.

Mrs. Hasan found a job cleaning houses. The work was hard, but she did not mind. Being able to contribute to her family's budget helped her to feel better about herself. "Besides, it is easier when I am not all alone and when I have less time to think about the changes that happened in our family."

As her children's English improved they made many friends, became better integrated in their school, and started to enjoy their life in America. They thought less and less about Bosnia, and more about the new and exciting opportunities for them in their new country. In our conversations, they spoke only in English, and we had to pause to translate to their mother, who appeared saddened. She told us: "I can not understand how our sons could forget their homeland so fast." Her husband was rarely at home, and they seldom had a chance to talk. Mrs. Hasan was trying to find a place for herself in this country and in her family. They did not seem to need her as much. She spoke of these feelings in our meetings, but otherwise, it was hard to find someone to talk with about her life.

By one year after her arrival in the US, her life seemed to change for the better. She had made the effort to make new friends in the mosque. Her English was sufficiently improved so that she could even become friendly with some of her American neighbours. She was able to do more basic things for her children without depending on her sponsors to navigate for her. She was feeling more independent and was taking charge of her new life. Her children's speedy and successful adjustment had buoyed her up.

The news from Bosnia was still grim, but she felt more a part of her family's life in America. "I am somewhat concerned about my parents in Bosnia. I have heard that they had been taken from their house, and were most likely killed." While talking about this her voice was calm and the disappearance of her anguish from a year before was remarkable. She had not forgotten about Bosnia, but her priorities were now more clearly set with her family here.

When we visited them three years into their new life, for the first time, Mr. Hasan greeted us at the door of the house that they now owned! Mrs. Hasan showed us around the house they had completely refurbished and told us how well the family was now doing. Their son got a scholarship to college, and the daughter was doing well at school. Mrs. Hasan looked years younger. She had lost weight and got a stylish haircut. She smiled and joined the conversation. She had a well-paying job, and was busy working on her new house together with her husband. She was active in the Bosnian community and in political advocacy for Bosnia, going to meetings with her children. Mr. Hasan was more comfortable spending time at home now that he felt that he was able to provide for his family with a house and comfortable living. Not only was this not the frightened and shattered women we had met three years ago, but in many ways, her life was also so different from what it was before the war.

\section{Mrs. Muhic}

Mrs. Muhic is in her early forties. She is an attractive, short-statured women. She grew up in the city, was a good student, and took music lessons. She went to the university, and was em- 
ployed in an accounting firm. When she was in her mid-twenties she met her husband and they got married. They lived in a mid-sized city in Bosnia. Even though they both came from traditional Muslim families, they were secular Muslims. Like so many Bosnians born after World War II, they felt themselves to be "Yugoslavs," meaning they did not identify themselves by their ethnic or religious identity. They have two teenage children, a girl and a boy.

Mrs. Muhic was successful at her job and was promoted several times. She was a hard and dedicated worker, and would have held one of the higherranked positions in the company in a few years. Her husband had an important position in his field. While maintaining a successful career, Mrs. Muhic said that she would never have sacrificed any part of her family life for her job. Her home, children and husband came first. They had a roomy apartment in the centre of the town and Mrs. Muhic had spent many afternoons decorating it. The Muhic family was considered to be well off in their community. Friends were a big part of Mrs. Muhic's life. Very frequently, at least once a week, they would have parties at their house. "We all lived together."

Before the war, Mrs. Muhic was an energetic, somewhat shy woman, content with her life, her stable marriage and her rewarding and not too demanding job. She felt secure and comfortable as a part of a couple, and would make most of her decisions in consultation with her husband. She derived her pleasure from being with her children, having friends over to her apartment and from knitting.

About a year before the actual Serbian attack, Mrs. Muhic noticed increased national awareness among her Serbian friends who started saying that they had been treated unjustly. Soon after, more obvious things started happening: non-Serbs were fired from jobs; she was not promoted, and her Serbian friends made more open militant statements. Their town was seized and taken over by the Serbian army. When Mr. Muhic refused to "volunteer" into the Serbian army, he was fired. Mrs. Muhic continued to work. "My co-workers called me by a made-up Serbian name, because if the authorities found I was Muslim, I would be fired." Several months later, she was fired.

I was worried daily for my life, the lives of my children, and especially my husband's life. He was taken for an "interrogation" for three days, and I thought he was dead. Soldiers would come to our house and take whatever pleased them, and then would ask our children where their father was keeping guns.

Several friends and distant relatives were reported dead or just "gone." They hardly slept during the night, expecting the pounding on the door by the Serbian soldiers. "The hardest thing for me was not being able to rely on my Serbian friends any more ... My best friend became a high ranking administrator in the Serbian government, and she defended killings as necessary." To leave legally was impossible for Muslims and Croats, but a couple of Serbian friends helped the Muhics to get adequate paper work for the price of their life savings. One of the things they handed over was the apartment they owned. With only a few bags, they left the town and went to Croatia, and then the U.S.

In Bosnia, Mrs. Muhic had been established in her profession and her community, with a clear vision of her future until the war. "I felt as if my life had stopped upon our arrival to this country." When we first saw her she looked very frightened, was not able to have extended eye contact, and could not sit comfortably in a chair. She could not get rid of constant intrusive memories, and the sense of being unsafe. She did not believe the future would bring anything positive for her.

Mrs. Muhic's husband started working, took care of the family's finances and negotiated their living arrangements. His knowledge of English was very good, and he did all of the communication with sponsors and officials. Mrs. Muhic would usually just sit and smile and not understand much of what was said. She felt powerless and useless but her efforts at learning English were very painful and slow. She was not able to communicate in English when she felt scared or uncomfortable with the person she was talking to.

Her husband had been fortunate enough to get a job in his field. She had to settle for a factory job. The work was hard, as she was not used to working with her hands. "There were many monotonous hours at work that gave me time to think about the changes that so suddenly affected my family, and how little I was in control of my life. People from work did not associate much with me, mostly because of my poor English, and I felt isolated, missing friendly chats from my Bosnian days."

Her daily routine consisted of going to work and taking care of their two children, doing house chores and occasionally visiting her cousin's family. She became acquainted with some women through the Bosnian refugee organization, but was hesitant to start any real friendships, since meeting new people usually meant talking about the hard times in Bosnia. She was also afraid of experiencing more disappointments or betrayals from new friends. At first she kept in touch with friends back in Bosnia. "I used to make regular phone calls, but the news was always grim, so gradually I cut down on the number of phone calls." She felt most comfortable when with her family.

Her husband was, however, advancing in his career and had made a larger number of acquaintances and friends. His life was much closer to what they had in Bosnia than hers. She had given up on her career ambitions and was not even considering looking for a job that would fit her qualifications better. She was most content when at home, decorating their modest apartment, so she would again have a security of having a home. She joked that she preferred to be a housewife now.

She spent a lot of time with her children especially her son who was refus- 
ing to speak Bosnian. He understood what she was saying in Bosnian, but was always answering in English. She saw this as his way of putting some space between his current life and the traumatic experiences in Bosnia. Still, Mrs. Muhic couldn't help but wonder if she was being the right kind of mother for her child. Overall, the children were doing well at school and had made American friends.

Her husband remained in charge of almost all the chores outside the house, and was making decisions about finances. She found herself trying to deal with her worries about Bosnia and at the same time wanted to find out more about herself-this person that had changed so much in three years. She brought some of these issues to our meetings. "A few years ago, I was able to plan my future. Not being able to plan far ahead made me insecure and afraid. I am trying to take charge of my life again."

She tries not to "bother" her husband with her worries. "He has enough responsibilities on his shoulders already." They are still very close. She describes him as her best friend, and also as somebody that she depends on greatly now. When she sees others in the Bosnian community, she often finds herself in the position of offering support and care to those less well off. She visits her cousin every few days. Mrs. Muhic tries to comfort her cousin the way Mr. Muhic is trying to encourage her. Mrs. Muhic can't talk about her own struggles with her cousin who lost several relatives in the war and suffers greatly.

Three years after their arrival in the United States, Mrs. Muhic's English has improved somewhat, but not enough for easy communication. She knows for sure that she wants to stay in the United States. "I do not want to go back to Bosnia and have my children live through my disappointments." She still has the same job, and she is not looking for a different one. In a few years, she hopes, she might be able to quit working altogether and stay at home. Its not what she expected for her life, but given all that they have been through, it seems pretty good to her.

\section{Discussion}

\section{The Refugee Women in the Private Sphere}

For the Bosnian refugee after ethnic cleansing, family is often the only remaining microsocial system in a chaotic and threatening social environment. For these refugee women at mid-life transition, family is the main pillar of their lives. Family has always been a central component of their lives, but as a refugee, there is a new sense of their participation in the family. The family's burden is also made more complicated, however, because the families who have survived genocide are comprised entirely of family members who were each severely traumatized, bringing many changes into the family and all its members.

A major theme Levinson identified in the mid-life transition of some women is that her caregiving to others lessens, and in place she wants to "make her own choices and pursue her own interests." These refugee women, on the other hand, are more occupied than ever, establishing and maintaining the home base for their families. Materially, it cannot be compared to the old home, but they strongly desire for it to provide some of the necessary supportive functions for their families.

They may be more of a caretaker to their husbands than ever before, especially when he has no job, speaks no English, and suffers from war traumas. Mid-life is often a time for changing a marriage that can seem no longer alive or rewarding. The marriages that survived ethnic cleansing have extraordinary additional strains. Wives may feel estranged from their husbands as a consequence of physical separations during the persecution, or the otherness of their respective trauma experiences. In some instances, wives may also be victimized by their husbands aggressiveness and domination.

The top priority for these refugee women was to take care of their children. Ironically, these women had oth- erwise been approaching the time when motherhood would no longer be the most central component of their lives. With their children growing further into adolescence and seeking more autonomy, as mothers they would be less needed to care for them.

The refugee experience both intensifies and marginalizes their role as mothers. There are new fears, challenges and stresses for the children which intensifies their need for mothering. Yet, as time goes on and the children adjust more rapidly to the new life than their parents, children need less mothering. The parents may need a stronger connections. When children are traumatized, being with them also means confronting one's own traumatic experiences, with the potential for empathic knowing, but also for confusion and distancing. Confounding this is the mother's felt obligation to care for the yet more needy: her parents, newer refugees, the wounded and ill. She feels pulled between the life force embodied in her growing children, and the marks of loss and death that are carried in other refugees lives and in her own memories. Her existence is defined by a struggle between the dehumanizing genocide experience and the potentially humanizing experience of the life process. At no point does the refugee woman's involvement with the one make them totally immune to the other. In their lives, we can find traces of constant, unending struggle in many different forms.

\section{The Refugee Women in the Public Sphere}

Levinson (1996) notes that work and career is most often the way that a woman finds an entrée into the public sphere. By and large, the only jobs available to these refugee women were unskilled or semi-skilled jobs. Both became labourers. Work often moves to occupy a larger position in the woman's life at mid-life. These refugee women are working more, but mostly out of financial necessity, not out of a sense of wanting, "to give more of themselves to the work, to receive 
more from it, and to participate in new ways within the work world" (ibid., 192). They both started at the bottom. For the homemaker, it turned out to be somewhat liberating. For the professional woman it was more stifling. When the home base and the children are more settled, the place of work can be addressed.

Like other survivors of political violence, refugee women face the challenge of understanding private suffering in a public context. The turn inwards towards the family, may work against the refugee woman formulating suffering in a public context. The experience of surviving nationalism and genocide, can compel the refugee mother to raise the boundary around the family private life, keeping the social issues out. The suffering that she experiences may be more readily formulated in personal terms, as psychological or somatic distress (making the idea of psychiatric or medical treatment somewhat more palatable for women than men). She may desire to shield her children from social issues related to Bosnia and the war.

We have also noticed that for some refugee women at mid-life, their children's curiosity and commitment regarding Bosnia, may offer another pathway into the public realm. She may support and encourage the children towards political and community activism, and even join with them in those activities. Through following and facilitating her growing children's forays into the world, she can further develop her families' connectedness with the world outside, and find a new sense of place in the public realm.

The refugee woman's life cannot be what it once was, and there will never be a resolution to many of the problems she faces. But where there is good enough daily means, a struggle to learn, and a dream of a better way, it becomes as recognizable, and perhaps even as acceptable, as any life on earth.

\section{Bibliography}

Agger, Inger. 1992. The Blue Room: Trauma and Testimony among Refugee Women; A Psy-
cho-Social Exploration. London and New Jersey: Zed Books Ltd.

Agger, Inger, and Soren Jensen. 1990. "Testimony as Ritual and Evidence in Psychotherapy for Political Refugees." Journal of Traumatic Stress 3, no. 1, 115-30

Arcel, L. T., V. Folnegovic-Smalc, D. KozaricKovacic, and A. Marusic. 1995 Psycho-Social Help to War Victims: Women Refugees and Their Families from Bosnia-Herzegovina and Croatia. International Rehabilitation Council for Torture Victims: Copenhagen.
Bringa, Tone. 1995. Being Muslim the Bosnian Way. Princeton and Chichester: Princeton University Press.

Levinson, Daniel J.1996. The Seasons of a Woman's Life. New York: Alfred Knopf.

Weine,S.M. 1996. “Refugees' Memories, Witnessing, and History after Dayton." 1996 World Refugee Survey, U.S. Committee for Refugees, 28-34.

Weine, S. M., D. Vojvoda, S. Hartman, and L. Hyman. 1997. “A Family Survives Genocide.” Psychiatry, Spring. ם

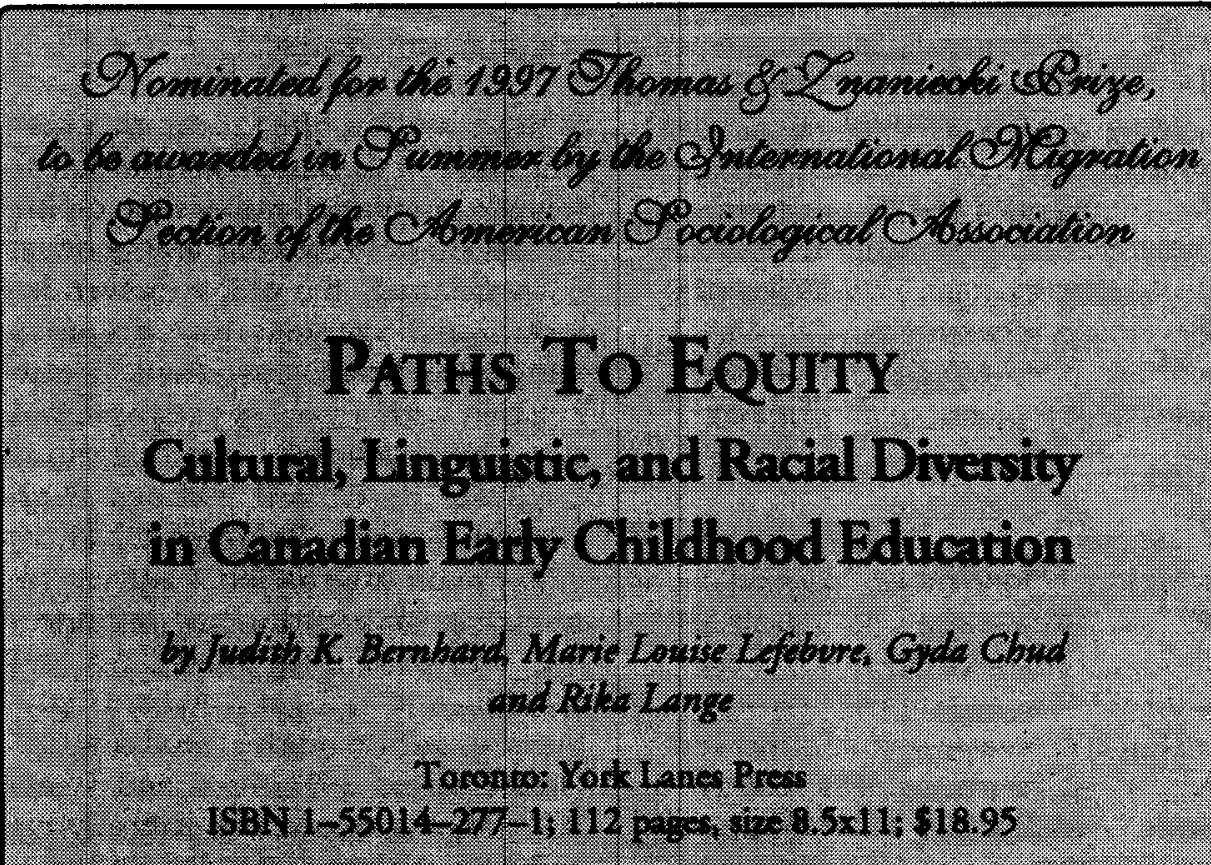

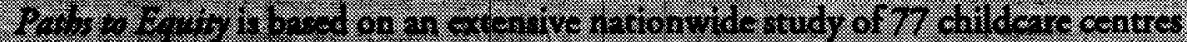

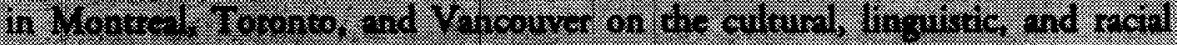

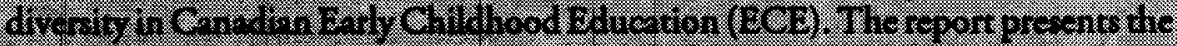

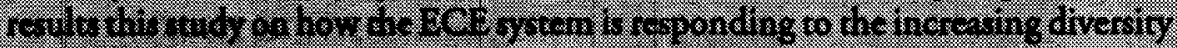

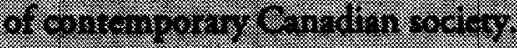

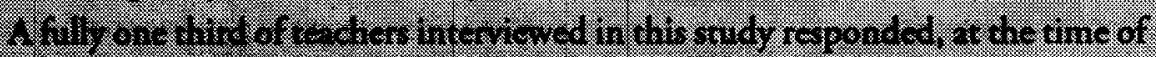
grot r.

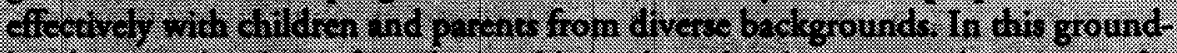

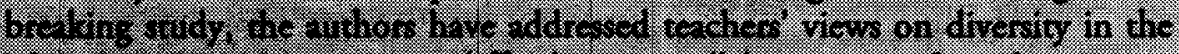

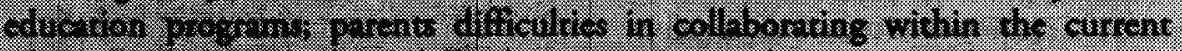

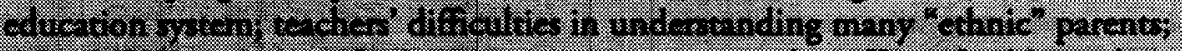

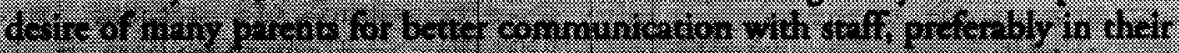

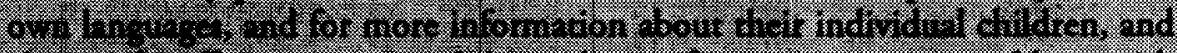

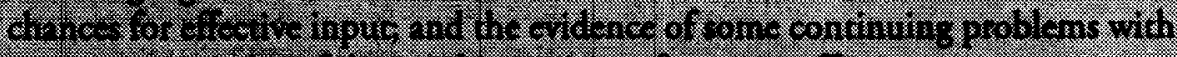

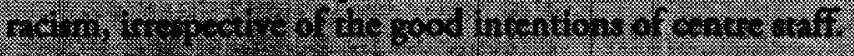

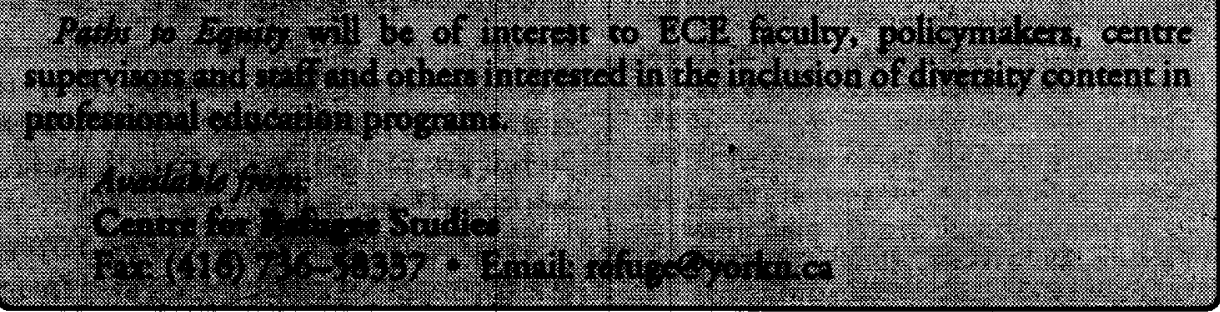

